\title{
Distribution and degradation of organic matter with different molecular weight in an $\mathrm{A}^{2} / \mathrm{O}$ treatment system
}

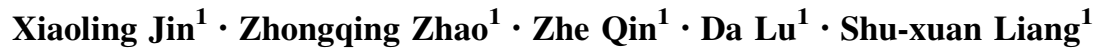

Received: 20 November 2015 / Accepted: 6 September 2017/Published online: 4 October 2017

(c) The Author(s) 2017. This article is an open access publication

\begin{abstract}
Organic matter (OM) fractions and their removal potentials in various stages of anaerobic-anoxic-oxic $\left(\mathrm{A}^{2} / \mathrm{O}\right)$ process were identified and evaluated. Molecular weight (MW) distribution of organic matter by continuous filtration method was used to characterize OM in influent and treated effluent. The results showed the MW of each reaction pool distributed in a $U$ shape and ranged with particle size $>0.45 \mu \mathrm{m}$ and molecular weight $<1 \mathrm{k}$ accounted for a high proportion. These results suggested effluent organic matter $<1 \mathrm{k}$ of an anoxic pool, anaerobic pool, and an aerobic pool in the $\mathrm{A}^{2} / \mathrm{O}$ treatment systems significantly outnumbered the other stages. Meanwhile, influent organic matter within the range $>0.45 \mu \mathrm{m}, 10-30$, $5-10$, and $<1 \mathrm{k}$ was well removed while organic matter in the MW range of 30-100 and 1-3 k was used at a low rate during $\mathrm{A}^{2} / \mathrm{O}$ treatment. Denitrification required an external carbon source in $30 \mathrm{mg} / \mathrm{L}$ (calculated as methanol) for ensuring efficient process operation. Experimental approaches in this study can be applied to evaluate and diagnose the function of water treatment process.
\end{abstract}

Keywords Molecular weight distribution - Organic matter - Wastewater treatment . Continuous filtration

Shu-xuan Liang

liangsx168@126.com

1 Key Laboratory of Hebei Provincial Analytical Science and Technology, College of Chemistry and Environmental Science, Hebei University, Baoding 071002, People's Republic of China

\section{Introduction}

Various types of organic matter in certain MW range express similar physiochemical characteristics (Mogens 1992). The MW distribution of organic matter plays an important role in researching the behaviors and degradation mechanisms of organic matter in water (Ebru et al. 2006; Chavez et al. 2004). In addition, the MW distribution of organic matter is also an important factor to consider in the water treatment process (Cuss et al. 2015; Tiina et al. 2008; Lin 2012; Sophonsiri et al. 2004). Stephen et al. (2000) found that in the treatment process, adsorption of humus to organic matter is impacted by its MW. The research of An et al. (2009) involving DOC removal indicated that organic matter of MWs smaller than $1 \mathrm{k}$ in DOC could be effectively removed using an ozone biochar process. Lepanea et al. (2003) found through experimentation that organic matter of high MWs in seawater were more easily degraded by UVB. To date, most domestic researches in the MW distribution of organic matter in water mainly targeted source water and artificial wetland systems (Tong et al. 2010; Wang et al. 2013; Zhao et al. 2006; Du et al. 2014). However, there were few reports about research linking MW distribution and evolution with the use efficiency of a carbon source. As for China, carbon source deficiency currently prevails, and a low carbon-to-nitrogen $(\mathrm{C} / \mathrm{N})$ ratio in wastewater treatment is highly difficult (Peng et al. 2009). Moreover, it heavily influences the removal of nitrogen and phosphorous in the wastewater treatment process (Kuba et al. 1996; Wang et al. 2014; Zhao et al. 2014; Gomez et al. 2002).

Set against the background of the $\mathrm{A}^{2} / \mathrm{O}$ process, while taking an urban low $\mathrm{C} / \mathrm{N}$ ratio of domestic wastewater as a study object and employing a MW cutoff approach, this experiment probes the degradation and optimal carbon source added to the amount of organic matter in various MW ranges.

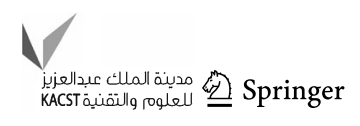


Furthermore, it aims to improve the efficiency of carbon source use and ensure a stable and efficient process operation.

\section{Materials and methods}

\section{Wastewater sampling}

Water samples were taken from a wastewater treatment plant that adopts $\mathrm{A}^{2} / \mathrm{O}$ process for its biological treatment. Samples collected in the primary sedimentation pool used as biological treatment influent and in the secondary sedimentation pool as biological treatment effluent. In addition, samples of primary anaerobic pool, anoxic pool, and aerobic pool were analyzed.

\section{Equipment}

Instruments used in this experiment included an HQ30d portable $\mathrm{pH}$ meter (Hash), an HQ30d portable dissolved oxygen meter (Hash), an ultrafiltration cup (Model 8200), and an ultraviolet and visible spectrophotometer (UV-2600).

\section{Experimental methods}

The membrane (PL series, Millipore) was soaked and rinsed three times (with smooth side facing downwards) using ultrapure water with the addition of a little ethanol, an hour for each time. Then, the membrane was cleaned using pure water and placed in a refrigerator. The filter membrane holes were cleaned with $100 \mathrm{~mL}$ of filtered pure water and then water samples were filtered.

Mud mixture samples were taken from various reaction pools, and left to stand and settle for $30 \mathrm{~min}$. Next, supernatant microfiltration and ultrafiltration separating techniques were employed for performing a physical and fractional pretreatment of the water samples. Then, the filtrate of different particle sizes was tested and analyzed to obtain the water quality characteristics of different components (show continuous filtration procedures in Fig. 1).

Conventional chemical parameters were measured, including $\mathrm{COD}, \mathrm{NH}_{3}-\mathrm{N}$, total nitrogen (TN), total phosphorous (TP), $\mathrm{pH}$, and dissolved oxygen (DO). The measurements were performed as described in the regulated standard methods.

\section{Results and discussion}

\section{Wastewater characteristics}

Major water quality parameters of various processes obtained in the experiment are listed in Table 1.

Influent with COD/TN smaller than 4 is typically a low $\mathrm{C} / \mathrm{N}$ ratio of wastewater (Fang et al. 2005). As the influent is very low in the $\mathrm{C} / \mathrm{N}$ ratio, the nitrification time is prolonged. In addition, denitrification lacks organic matter as electron donors. In this case, the denitrification rate is lowered and the degradation of nitrogen containing compounds is affected. Through the $\mathrm{A}^{2} / \mathrm{O}$ treatment system, the removal rates of $\mathrm{NH}_{3}-\mathrm{N}, \mathrm{TN}$, and $\mathrm{TP}$ are at 79,72 , and $61 \%$, respectively, and they all fall short of the primary grade-A emission standard. Moderate $\mathrm{pH}$ and DO are also required for efficient operation of the $\mathrm{A}^{2} / \mathrm{O}$ process. In the $\mathrm{A}^{2} / \mathrm{O}$ process, $\mathrm{pH}$ and $\mathrm{DO}$ mostly influence nitrification and denitrification. Nitrobacteria are very sensitive to $\mathrm{pH}$ changes, and the optimum range is believed to be from 7.5 to 8.5 . When the $\mathrm{pH}$ value is lower than 7 , the nitrification rate drops remarkably, and the nitrification will stop when the $\mathrm{pH}$ value is lower than 6 or higher than 9.5. Oxygen is an electron accepter in the process of nitrification, while the DO level in a reactor definitely has an effect on nitrification. In general, the DO concentration of mixed liquid should be maintained at 2-3 mg/L. During denitrification, the most moderate $\mathrm{pH}$ value ranges between 6.5 and 7.5 ; otherwise, the growth speed of denitrification bacteria and activity of denitrification enzyme will be affected. DO plays a great inhibition role in the process of denitrification. It is generally recognized that denitrification can only normally proceed when DO in the system is kept lower than $0.5 \mathrm{mg} / \mathrm{L}$.

\section{Optimization of the external carbon source in $\mathrm{A}^{2} / \mathrm{O}$ system}

Organic matter (calculated as COD) in wastewater is classified into particulate and soluble COD. COD with a

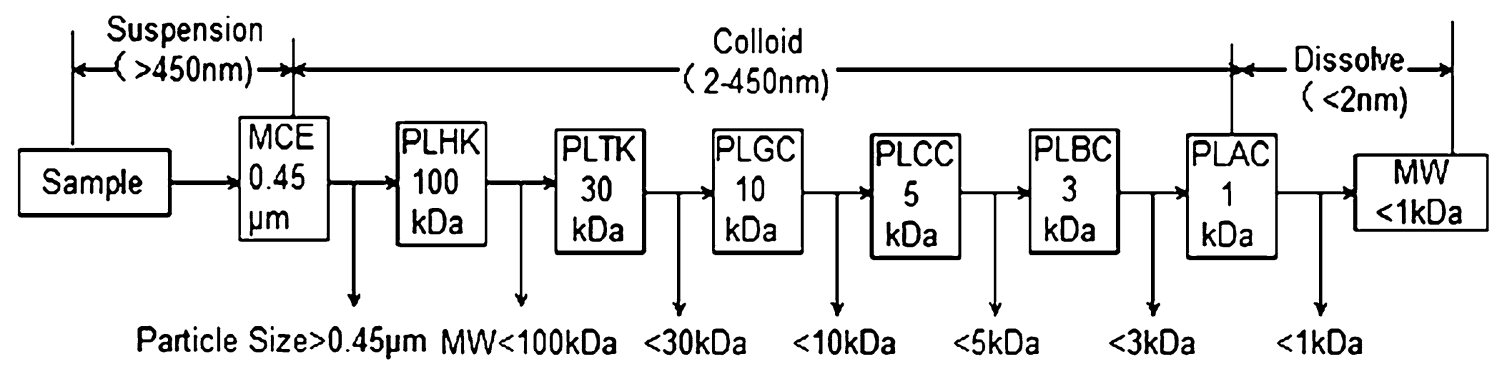

Fig. 1 Schematic view of continuous filtration procedures 
Table 1 Results of major indicators in processes

\begin{tabular}{|c|c|c|c|c|c|c|}
\hline Processes & $\mathrm{COD}(\mathrm{mg} / \mathrm{L})$ & $\mathrm{pH}$ & $\mathrm{NH}_{3}-\mathrm{N}(\mathrm{mg} / \mathrm{L})$ & $\mathrm{TN}(\mathrm{mg} / \mathrm{L})$ & $\mathrm{TP}(\mathrm{mg} / \mathrm{L})$ & $\mathrm{DO}(\mathrm{mg} / \mathrm{L})$ \\
\hline Influent & 197.9 & 8.15 & 39.19 & 56.72 & 12.57 & 2.8 \\
\hline Anaerobic pool & 153.5 & 7.47 & 18.70 & 41.91 & 54.27 & 0.1 \\
\hline Anoxic pool & 142.3 & 7.39 & 15.15 & 31.17 & 38.39 & 0.5 \\
\hline Aerobic pool & 184.1 & 7.62 & 12.32 & 27.67 & 12.75 & 3.3 \\
\hline Effluent & 96.7 & 7.50 & 8.21 & 15.84 & 4.79 & 4.1 \\
\hline
\end{tabular}

particle size larger than $0.45 \mu \mathrm{m}$ are particulate COD $(\mathrm{X})$ or are soluble COD (S) with a particle size smaller than $0.45 \mu \mathrm{m}$. Figure 2 reflects organic matter changes of various processes in the $\mathrm{A}^{2} / \mathrm{O}$ system.

As the reaction continues, the total amount of total organic matter, particulate organic matter, and dissolved organic matter somewhat decreases. The reason is that they are converted into organic matter with a low MW when as a carbon source of the system in the reaction and are consumed to be biochemically reacted with the original soluble organic matter. In the $\mathrm{A}^{2} / \mathrm{O}$ process, the nitrification stage takes autotrophic nitrobacteria as the dominant species. The autotrophic nitrobacteria utilize ammonia in wastewater as energy and $\mathrm{CO}_{2}$ as a sole carbon source to convert ammonia into $\mathrm{NO}_{2}^{-}$and $\mathrm{NO}_{3}{ }^{-}$, and obtain energy for their growth needs simultaneously, thus enabling $\mathrm{CO}_{2}$ to synthesize cellular organic matter. With no organic matter as the carbon source, there are no constraints from the low organic matter concentration in the course of nitrification. $\mathrm{C} / \mathrm{N}$ mainly effects denitrification. Denitrification bacteria use oxygen of nitrate as electron acceptors in an anaerobic environment and organic matter in wastewater as the carbon source and the electron donor to supply energy and stabilize oxidation. When wastewater lacks organic matter, microorganisms consume their own protoplasm for endogenous denitrification, which reduces cellular matter and generates $\mathrm{NH}_{3}$. Thus, it can

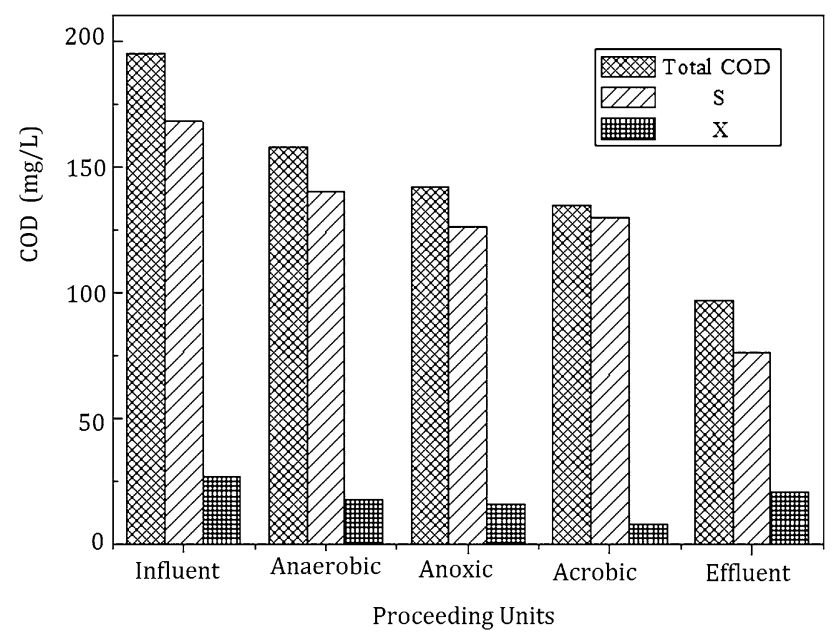

Fig. 2 The total change of effluent organic matter at various processes be seen that the carbon source is of great importance in denitrification. If the $\mathrm{C} / \mathrm{N}$ ratio is too low, then denitrification lacks a carbon source, which leads to incomplete denitrification and a failure to remove nitrogen.

When possessing a relatively low $\mathrm{C} / \mathrm{N}$ ratio, wastewater is dosed with a large quantity of organic carbon sources to meet the nitrogen emission standard. If the dosage is too low, the effluent nitrate concentrations may exceed the standard and the effluent water quality will fail to meet the requirement. Likewise, if the dosage is too high, the operation cost will be increased and the effluent water quality is likely to deteriorate (Cho et al. 2002). By examining the nitrification speed, denitrification speed, TN emission requirements, operation cost, etc. Jin et al. (2003) showed that when the S/TN is approximately 5 in the denitrification stage, the treatment efficiency and operation stability could be ensured. As shown in Table 1 and Fig. 2, the $\mathrm{S} / \mathrm{TN}$ in the anoxic denitrification stage is approximately 4.1 without an external carbon source. Moreover, in order to enhance denitrification efficiency, the external carbon source in $30 \mathrm{mg} / \mathrm{L}$ (calculated as methanol) is dosed in an anoxic pool. By adopting methanol as the external carbon source, a high denitrification speed and nitrogen removal rate are realized, along with a low operation cost. Beneficially, the rate of the carbon source use is improved and the operation cost of enterprises is reduced.

\section{Molecular weight distribution of $\mathrm{OM}$ in $\mathrm{A}^{2} / \mathrm{O}$ treatment processes}

\section{Molecular weight comparisons between influent and effluent}

After continuously filtering the biological influent and effluent samples in the experiment by referencing the COD values of the filtrate in different particle sizes, a subtraction method was used to obtain the COD differences between the two adjacent filter membranes. The COD distribution of different particlesize components was then recorded (Fig. 3, MW is expressed in "k Dalton" as abbreviated by "k").

As shown in Fig. 3, the MW distribution of organic matter in municipal wastewater features a $U$ shape, mostly above $100 \mathrm{k}$ and below $1 \mathrm{k}$. Through $\mathrm{A}^{2} / \mathrm{O}$ treatment, the organic matter in most MW distribution ranges can be 


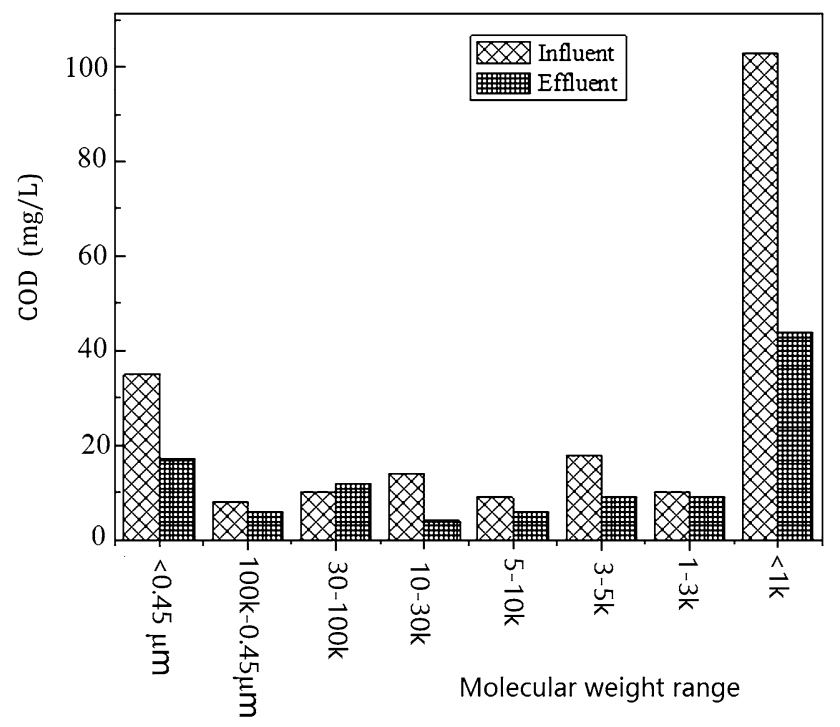

Fig. 3 Molecular weight distribution of influent and effluent organic matter

effectively degraded, and the use rates of the organic matter in the MW distribution ranges $>0.45 \mu \mathrm{m}, 100 \mathrm{k}-$ $0.45 \mu \mathrm{m}, 30-100,10-30,5-10,3-5,1-3$, and $<1 \mathrm{k}$, are $57.76,8.64,5.26,71.64,52.87,46.83,7.95$, and $58.17 \%$, respectively. The use rates of the organic matter in the MW distribution ranges $>0.45 \mu \mathrm{m}, 10-30,5-10$, and $<1 \mathrm{k}$ are high, all above 50\%. Therefore, one can see that the organic matter in these ranges can easily be degraded by the $\mathrm{A}^{2} / \mathrm{O}$ system. While the use rates of the organic matter in the MW distribution ranges of $100 \mathrm{k}-0.45 \mu \mathrm{m}, 30-100$, and $1-3 \mathrm{k}$ remain low, being, respectively, lower than $10 \%$. This reflects that the organic matter in these ranges is hard to degrade by the $\mathrm{A}^{2} / \mathrm{O}$ process.

Based on Fig. 4, the effluent organic matter in the ranges $>0.45 \mu \mathrm{m}, 10-30$ and $<1 \mathrm{k}$ have proportionally decreased to some extent in comparison to the influent organic matter under the condition that the COD of effluent is lower than influent. Essentially, the ranges of 3-5 and 5-10 k remain proportionally stable, while the ranges of $100 \mathrm{k}-0.45 \mu \mathrm{m}$,
30-100 and 1-3 k have proportionally increased slightly. MW distribution of soluble organic matter in various ranges changed during the wastewater treatment process. Macromolecular was converted into a micromolecular dissolved state and further converted into micromolecular organic matter to be consumed by microorganisms.

\section{Molecular weight distribution in separate reaction pools}

The MW distribution of organic matter in the reaction pools was shown in Fig. 5.

The MW distribution of influent and effluent organic matter in various reaction pools also exhibits a $U$ shape. Organic matter in water is successively used, degraded, and converted in the $\mathrm{A}^{2} / \mathrm{O}$ process. In addition, the use states of the organic matter in different ranges of MW are diverse from each other in the reaction pools of the $\mathrm{A}^{2} / \mathrm{O}$ process. Figure 5 indicates that effluent organic matter $<1 \mathrm{k}$ of the anoxic pool, the anaerobic pool, and the aerobic pool in the $\mathrm{A}^{2} / \mathrm{O}$ system are distinctly more than those in other ranges. The micromolecular weight of such organic matter accounts for a high proportion, and the organic matter content (calculated as COD) in this range of the reaction pools are 76.6, 66.1, and $56.5 \mathrm{mg} / \mathrm{L}$, accounting for 49.9 , 47.2 , and $46.1 \%$, respectively. Therefore, as shown, organic matter is like humic acid, and those environmental hormones not removed by the biological treatment exist in the form of micromolecules (Wang et al. 2009). Although the distribution of organic matter in most of the ranges becomes lower and lower as the reaction progresses, only aerobic effluent in the ranges of $100 \mathrm{k}-0.45 \mu \mathrm{m}, 10-30$ and $3-5 \mathrm{k}$ increases slightly as compared with anoxic effluent. The reason is that the ranges of $100 \mathrm{k}-0.45 \mu \mathrm{m}$ and $10-30 \mathrm{k}$ are macromolecular ranges in soluble organic matter, and the system adds filler to an aerobic area as to increase the biomass of the aerobic pool and supply more bio-flocculates to release macromolecular extracellular polymers and cellular autolysate from sludge. In an anaerobic and aerobic reaction, the organic matter of MWs
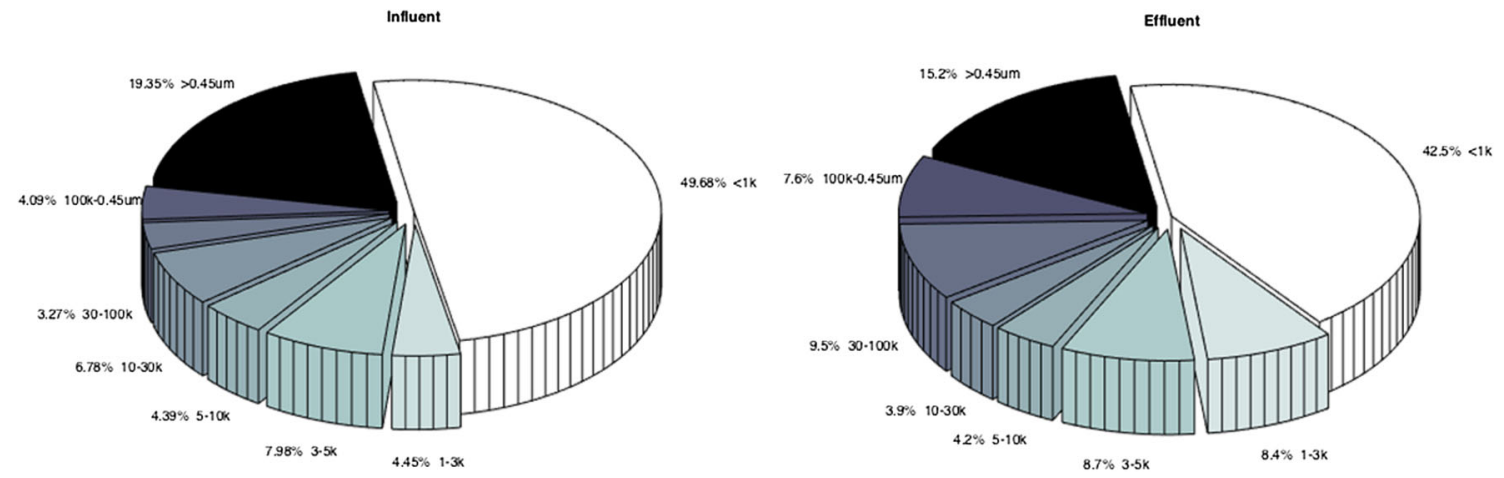

Fig. 4 COD distribution proportion in biological influent and effluent 


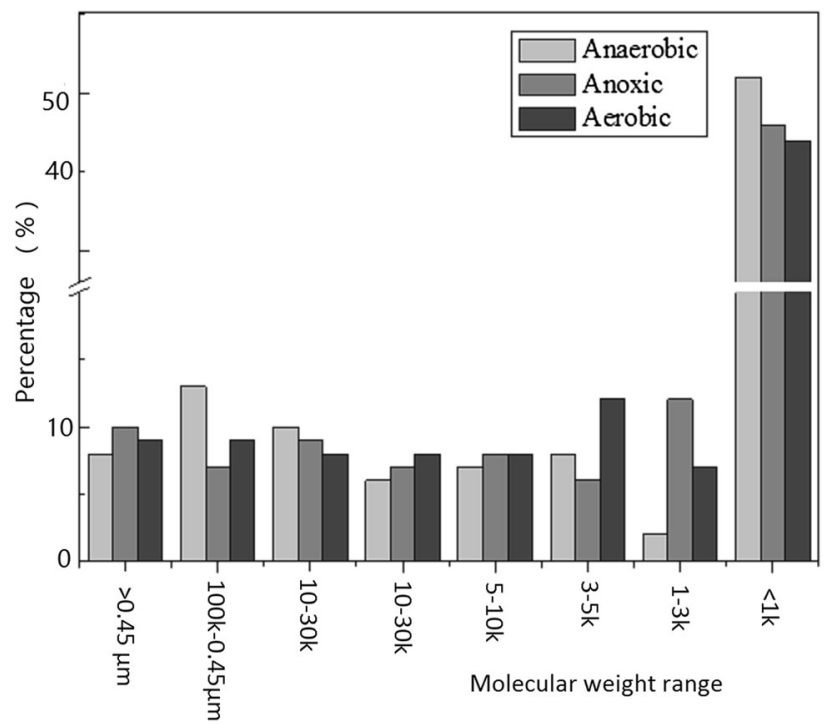

Fig. 5 The proportion of MW distribution of organic matter in reaction pools

above $10 \mathrm{k}$ is constantly converted into those in the range of 3-5 k, which results in a higher organic matter distribution in this range of the aerobic effluent than that of the anoxic effluent.

\section{Conclusion}

Experimental approaches in this study can be applied to evaluate and diagnose the function of water treatment process. A low-C/N-ratio wastewater mainly impacts denitrification in the $\mathrm{A}^{2} / \mathrm{O}$ process, and the external carbon source in $30 \mathrm{mg} / \mathrm{L}$ (calculated as methanol) can ensure treatment efficiency and operational stability of such process. After treated by the $\mathrm{A}^{2} / \mathrm{O}$ system, the organic matter in the MW ranges of 30-100 and 1-3 k has a low degradation rate. In addition, those in the range $<1 \mathrm{k}$ account for the highest proportion and can only be discharged up to the standard upon undergoing a deep treatment through ozone and so on.

Acknowledgements This work was supported by the Chinese 12th 5-year Major Science and Technology Project on Control and Prevention of Water Pollution (2012ZX07203-003) and Science and Technology Research Project of University in Hebei Province (ZD2017207).

Open Access This article is distributed under the terms of the Creative Commons Attribution 4.0 International License (http:// creativecommons.org/licenses/by/4.0/), which permits unrestricted use, distribution, and reproduction in any medium, provided you give appropriate credit to the original author(s) and the source, provide a link to the Creative Commons license, and indicate if changes were made.

\section{References}

An D, Song JX, Gao W, Chen GG, Gao NY (2009) Molecular weight distribution for NOM in different drinking water treatment processes. Desalination Water Treat 5:267-274

Chavez A, Jimenez B, Maya C (2004) Particle size distribution as a useful tool for microbial detection. Water Sci Technol 50:179-186

Cho JH, Sung SW, Lee IB (2002) Cascade control strategy for external carbon dosage in predenitrifying process. Water Sci Technol 45:53-60

Cussa CW, Gueguenb C (2015) Relationships between molecular weight and fluorescence properties for size-fractionated dissolved organic matter from fresh and aged sources. Water Res 68:487-497

Du XL, Xu ZX, Li JQ, Zheng L (2014) Characterization and removal of dissolved organic matter in a vertical flow constructed wetland. Ecol Eng 73:610-615

Ebru D, Serdar D, Oezlem K, Derin O (2006) Size distribution of wastewater COD fractions as an index for biodegradability. Water Res 40:273-282

Fang Q, Wei CH, Zhang CS, Zhang KF (2005) Simultaneous nitrogen and phosphate removal of municipal wastewater with character of unreasonable ratios of C/N/P. Technol Equip Environ Pollut Control 6:46-50

Gomez MA, Hontoria E, Gonzalez J (2002) Effect of dissolved oxygen concentration on nitrate removal from groundwater using a denitrifying submerged filter. J Hazard Mater 90:267-278

Jin CJ, She ZL, Gao JS (2003) Determination of demand of external carbon source for biological nitrogen removal of wastewater with low C/N ratio. Res Environ Sci 16:37-40

Kuba T, Loosdrecht MC, Heijnen JJ (1996) Phosphorus and nitrogen removal with minimal $\mathrm{COD}$ requirement by integration of denitrifying dephosphatation and nitrification in a two-sludge system. Water Res 30:1702-1710

Lepanea V, Persson T, Wedborga M (2003) Effects of UV-B radiation on molecular weight distribution and fluorescence from humic substances in riverine and low salinity water. Estuar Coast Shelf Sci 56:161-173

Lin YH (2012) Molecular weight distribution of organic matter by ozonation and biofiltration. Water Sci Technol 66:2604-2612

Mogens H (1992) Characterization of wastewater for modeling of activated sludge process. Water Sci Technol 25:1-15

Peng YZ, Ma B (2009) Efficiently biological nitrogen removal on condition of low C/N. Environ Sci 29:225-230

Sophonsiri C, Morgenroth E (2004) Chemical composition associated with different particle size fractions in municipal, industrial, and agricultural wastewaters. Chemosphere 55:691-703

Stephen E, Cabaniss SE, Zhou QH, Maurice P (2000) A log-normal distribution model for the molecular weight of aquatic fulvic acids. Environ Sci Technol 34:1103-1109

Tiina L, Hannu N, Risto P, Jaakko K, Toivo K, Jaakko P (2008) Effect of biological wastewater treatment on the molecular weight distribution of soluble organic compounds and on the reduction of $\mathrm{BOD}, \mathrm{COD}$ and $\mathrm{P}$ in pulp and paper mill effluent. Water Res 42:3952-3960

Tong ZG, Kang CX (2010) Molecular weight distribution and removal characteristics in source water of Ganjiang River. Adv Mater Res 113:1007-1012

Wang L, Tu XD, Liu Y (2009) Characteristics of residual organics MW distribution in the secondary effluent and experimental study of applicable pretreatment for membrane. J Environ Sci 29:75-80 
Wang Y, Zhang D, Shen ZY, Feng CH, Chen J (2013) Revealing sources and distribution changes of dissolved organic matter (DOM) in pore water of sediment from the Yangtze Estuary. PLoS One 8:1-10

Wang YL, Li J, Jia WJ, Wang N, Wang HB, Zhang S, Chen GH (2014) Enhanced nitrogen and phosphorus removal in the $\mathrm{A}^{2} / \mathrm{O}$ process by hydrolysis and acidification of primary sludge. Desalination Water Treat 52:5144-5151

Zhao ZY, Gu JD, Fan XJ, Li HB (2006) Molecular size distribution of dissolved organic matter in water of the Pearl River and trihalomethane formation characteristics with chlorine and chlorine dioxide treatments. J Hazard Mater 134:60-66
Zhao Y, Zhang Y, Ge Z, Hu C, Zhang H (2014) Effects of influent $\mathrm{C} / \mathrm{N}$ ratios on wastewater nutrient removal and simultaneous greenhouse gas emission from the combinations of vertical subsurface flow constructed wetlands and earthworm eco-filters for treating synthetic wastewater. Environ Sci 16:567-575

\section{Publisher's Note}

Springer Nature remains neutral with regard to jurisdictional claims in published maps and institutional affiliations. 